Becwar MR, Wann SR, Johnson MA, Verhagen SA, Feirer RP, Nagmani $R$ (1988) Development and characterization of in vitro embryogenic systems in conifers. In: Somatic cell genetics of woody plants, Kluwer Academic Publishers, Dordrecht, The Netherlands, pp 1-18

Brettell RIS, Dennis ES, Scowcroft WR, Peacock WJ (1986) Molecular analysis of a somoclonal variant of maize alcohol dehydrogenase. Mol Gen Genet 202:235-239

Buchholz JT, Stiemert ML (1945) Development of seeds and embryos in $P$ inus ponderosa, with special reference to seed size. Trans IIl Acad Sci 38:27-50

Cheliak WM, Pitel JA (1984a) Techniques for starch gel electrophoresis of enzymes from forest tree species. Information Report PI-X-42 Petawawa National Forestry Institute, Canadian Forestry Service, Government of Canada Cheliak WM, Pitel JA (1984b) Genetic control of allozyme variants in mature tissues of white spruce trees. J Heredity 75:34-40

Dhillon BS, Raman H, Brar DS (1989) Somatic embryogenesis in Citrus paradis and characterization of regenerated plants. Acta Hort 239:113116

Hakman I, von Arnold S (1985) Plantlet regeneration through somatic embryogenesis in Picea abies (Norway spruce). J Plant Physiol 121:149-158

Karp A, Steele SH, Parmar S, Jones MGK, Shewry PR, Breiman A (1987) Relative stability among barley plants regenerated from cultured immature embryos. Genome 29:405-412

King NN, Dancik BP, Dhir NK (1984) Genetic structure and mating system of white spruce (Picea glauca) in a seed production area. Can J For Res 14:639-643

Larkin PJ, Banks PM, Phasic R, Brettell RIS, Davies PA, Ryan SA, Scowcroft Wr, Spindler LH, Tanner GJ (1989) From somatic variation to variant plants: mechanisms and applications. Genome 31:705-711

Lassner MW, Orton TJ (1983) Detection of somatic variation. In: Tanksley SD, Orton TJ (eds) Isozymes in Plant Genetics and Breeding, Part A, Elsevier Science Publisher B.V Amsterdam, pp 207 217

Maheswaran G, Williams EG (1987) Uniformity of plants regenerated by direct somatic embryogenesis from zygotic embryos of Trifolium repens. Annals Bot 59:93-97

Mo LH, von Arnold S, Lagercrantz U (1989) Morphogenic and genetic stability in longterm embryogenic cultures and somatic embryos of Norway spruce (Picea abies [L.] Karst). Plant Cell Reports 8:375-378
Moore GA, Litz RE (1984) Biochemical markers for Carica papaya, $C$. cauliflora, and plants from somatic embryos of their hybrid. J Amer Soc Hort Sci 109:213-218

Noh E-W, Minocha SC (1990) Pigment and isozyme variation in aspen shoots regenerated from callus culture. Plant cell, Tissue and Organ Culture 23:39-44

Orton TJ (1983) Spontaneous electrophoretic and chromosomal variability in callus cultures and regenerated plants of celery. Theor Appl Genet 67:17-24

Roberts DR, Sutton BC, Flinn BS (1990a) Synchronous and high frequency germination of interior spruce somatic embryos following partial drying at high relative humidity. Can J Bot 68:1086-1090

Roberts DR, Flinn BS, Webb DT, Webster FB, Sutton BCS (1990b) Abscisic acid and indole-3-butyric acid regulation of maturation and accumulation of storage proteins in somatic embryos of interior spruce. Physiol Plant 78:355-360

Ryan SA, Scowcroft WR (1987) A somaclonal variant of wheat with additional B-amylase isozymes. Theor Appl Genet 73:459464

Scowcroft WR (1984) Genetic variability in tissue culture: impact on germplasm conservation and utilization. International Board for Plant Genetic Resources Report, Food and Agriculture Organization of the United Nations, Rome

Thorpe TA (1988) In vitro somatic embryogenesis. ISI Atlas of Science, Animal and Plant Sciences pp 81-88

von Amold $S$, Eriksson $T$ (1977) A revised medium for growth of pea mesophyll protoplasts. Physiol Plant 39:257-266

von Amold S, Hakman I (1988) Regulation of somatic embryo development in Picea abies by abscisic acid (ABA). J Plant Physiol 132:164-169

Wang H, Holl FB (1988) In vitro culture and the incidence of somaclonal variation in regenerated plants of Trifolium pratense $\mathrm{L}$. Plant Sci 55:159-167

Webb DT, Webster F, Flinn BS, Roberts Dr, Ellis DD (1989) Factors influencing the induction of embryogenic and caulogenic callus from embryos of Picea glauca and $P$. engelmanii. Can J For Res 19:13031308

Webster FB, Roberts DR, Mclnnis SM, Sutton BCS (1990) Propagation of interior spruce by somatic embryogenesis. Can J For Res 20:17591765

\title{
Erratum
}

Due to an unfortunate error, indication of the date of reception and the Communicating Editor for the article "Reduced intracellular content of methotrexate in an isolated MTX-resistant cell line of Nicotiana plumbaginifolia" by Rivka Barg and Sara Shabtai in Volume 10, Issue 5, 1991 pp. 269-272 were omitted. The complete information is given below:

Plant Cell Reports (1991) 10:269-272

\section{Reduced intracellular content of methotrexate in an isolated MTX-resistant cell line of Nicotiana plumbaginifolia}

\author{
Rivka Barg and Sara Shabtai
}

Department of Plant Genetics and Breeding, The Volcani Center, Agricultural Research Organization, Bet Dagan, Israel, 50-250

Received January 28, 1991/Revised version received May 24, 1991 - Communicated by R. N. Beachy 